\title{
Evaluation of Gas Reburning and Low-NO Burners on a Wall-Fired Boiler A DOE Assessment
}

February 2001

U.S. Department of Energy

National Energy Technology Laboratory

P.O. Box 880, 3610 Collins Ferry Road

Morgantown, WV 26507-0880

and

P.O. Box 10940, 626 Cochrans Mill Road Pittsburgh, PA 15236-0940

website: www.netl.doe.gov

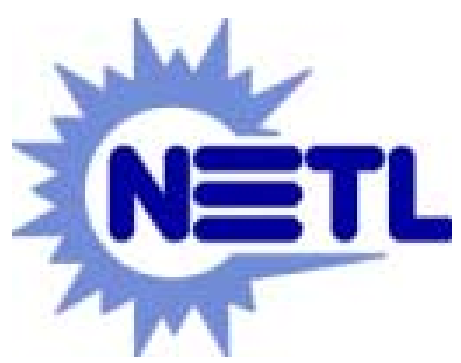




\section{Disclaimer}

This report was prepared as an account of work sponsored by an agency of the United States Government. Neither the United States Government nor any agency thereof, nor any of their employees, makes any warranty, express or implied, or assumes any legal liability or responsibility for the accuracy, completeness, or usefulness of any information, apparatus, product, or process disclosed, or represents that its use would not infringe privately owned rights. Reference therein to any specific commercial product, process, or service by trade name, trademark, manufacturer, or otherwise does not necessarily constitute or imply its endorsement, recommendation, or favoring by the United States Government or any agency thereof. The views and opinions of authors expressed therein do not necessarily state or reflect those of the United States Government or any agency thereof. 


\section{EXECUTIVE SUMMARY}

This document serves as a U.S. Department of Energy (DOE) post-project assessment of a project in its Clean Coal Technology (CCT) Program, Round 3, "Evaluation of Gas Reburning and Low-NO Burners on a Wall-Fired Boiler," conducted by Energy and Environmental Research Corporation (EER). In October 1990, EER entered into a cooperative agreement with DOE to conduct this study, with the Gas Research Institute (GRI), the Electric Power Research Institute, Public Service Company of Colorado (PSCo), and Colorado Interstate Gas Company as the other project participants. The demonstration was conducted between October 1992 and January 1995 on PSCo's 158-MWe (net) wall-fired Cherokee Station Unit 3 located in Denver, Colorado. Unit 3 is a 172MWe wall-fired boiler that uses Colorado bituminous, low-sulfur coal. Over 4,000 hours of operation were achieved. Low- $\mathrm{NO}_{\mathrm{x}}$ burners achieved a $\mathrm{NO}_{\mathrm{x}}$ reduction of $65 \%$ at an average gas heat input of $18 \%$ compared to the performance goal of $70 \%$. The performance goal of $70 \%$ reduction was met on many runs, but at higher gas heat inputs. DOE provided $50 \%$ of the total project funding of $\$ 17.8$ million.

Gas reburning (GR) involves firing natural gas (up to $25 \%$ of total heat input) above the primary combustion zone in utility boilers and industrial furnaces. This upper-level firing creates a slightly fuel-rich zone. $\mathrm{NO}_{\mathrm{x}}$ produced in the primary zone of the boiler is "reburned" in this zone and converted to molecular nitrogen and other reduced nitrogenous species. Overfire air is injected downstream of the reburn zone to burn out the remaining combustibles and convert the reduced nitrogenous species to molecular nitrogen. Low- $\mathrm{NO}_{\mathrm{x}}$ burners (LNBs) positioned in the coal combustion zone retard the production of $\mathrm{NO}_{\mathrm{x}}$ by staging the burning process so that the coal-air mixture can be carefully controlled at each stage. The combination of these two technologies is referred to as GR-LNB. The combined effect of adding a reburning stage to wall-fired boilers equipped with LNBs was intended to lower $\mathrm{NO}_{\mathrm{x}}$ emissions by up to $70 \%$. In this project, GR was operated with and without the use of flue gas recirculation. 
The objectives for this project were:

- To attain up to $70 \%$ reduction in $\mathrm{NO}_{\mathrm{x}}$ emissions from an existing wall-fired utility boiler firing low-sulfur coal

- $\quad$ To assess the impact of GR-LNB on boiler performance

The project could not meet these objectives except for short-term tests, in which very high reburn gas heat input was used. Boiler operability was found acceptable in long-term testing. No significant adverse boiler impacts were observed, such as large decreases in thermal performance or electrostatic precipitator collection efficiency. Other emissions impacts on air, water, and land remained within acceptable limits.

Economics of the GR-LNB process have been estimated for a hypothetical 300-MWe cyclone boiler fired with 3\% sulfur coal, and assuming a $\$ 1 / 10^{6}$ Btu price differential between gas and coal fuels. The capital cost is estimated at $\$ 26 / \mathrm{kWe}$ and the 15 -year levelized cost is estimated at $\$ 1,027 /$ ton of $\mathrm{NO}_{\mathrm{x}}$ removed (current dollar basis). 


\section{TABLE OF CONTENTS}

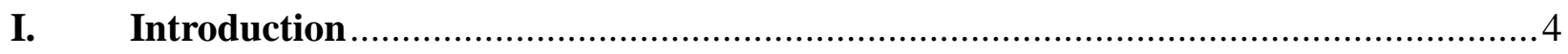

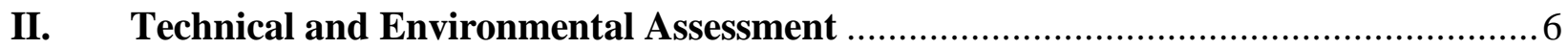

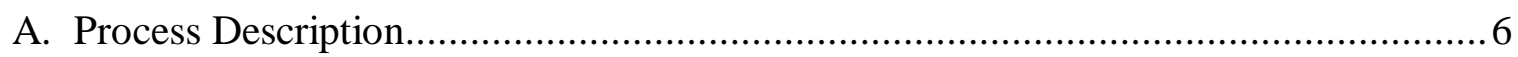

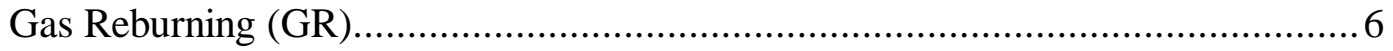

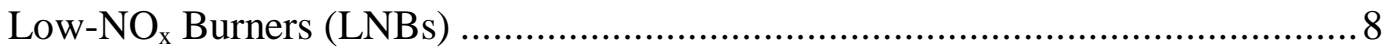

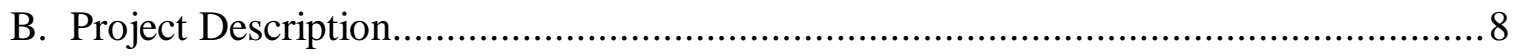

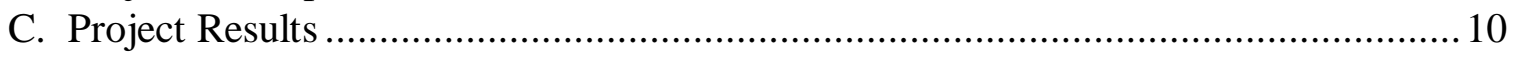

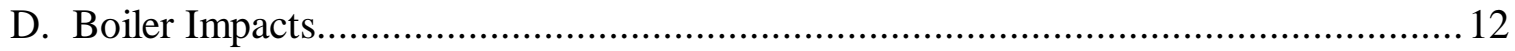

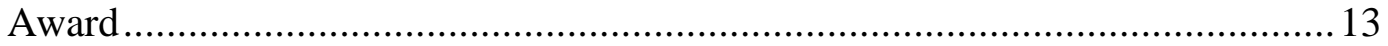

E. Commercialization of the Technology …………….............................................. 13

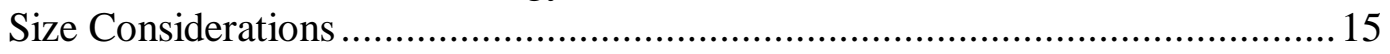

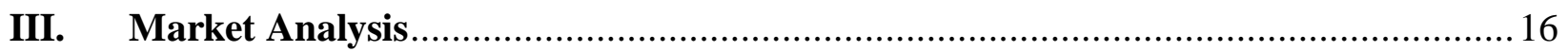

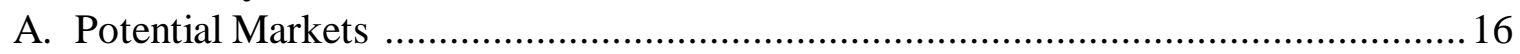

B. Economic Assessment of Utility Boiler Applications.................................................17

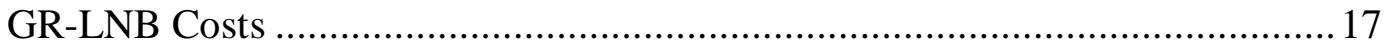

Comparison with Other Technologies............................................................... 17

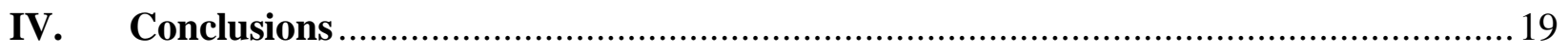

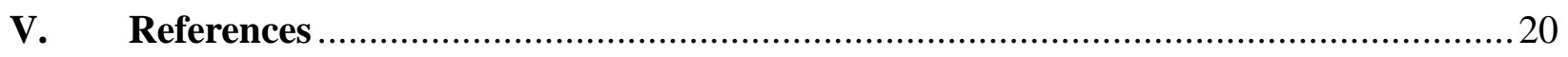




\section{INTRODUCTION}

The goal of the U.S. Department of Energy's (DOE) Clean Coal Technology (CCT) program is to furnish the energy marketplace with a number of advanced, more efficient, and environmentally responsible coal-utilization technologies through demonstration projects. These projects seek to establish the commercial feasibility of the most promising advanced coal technologies that have developed beyond the proof-of-concept stage.

This document is a DOE post-project assessment of a project selected in CCT Round 3, "Evaluation of Gas Reburning and Low- $\mathrm{NO}_{\mathrm{x}}$ Burners on a Wall-Fired Boiler," as described in a Report to Congress [1] dated September 1990. In October 1990, Energy and Environmental Research Corporation (EER) entered into a cooperative agreement to conduct this study. Other project participants were the Gas Research Institute (GRI), the Electric Power Research Institute (EPRI), Public Service Company of Colorado (PSCo), and Colorado Interstate Gas Company. The host site was PSCo's 158-MWe (net) wall-fired Cherokee Station Unit 3, located in Denver, Colorado. DOE provided $50 \%$ of the total project cost of $\$ 17.8$ million. Baseline testing was started in October 1992, and field testing was completed in January 1995.

Gas reburning (GR) involves firing natural gas (up to $25 \%$ of the total heat input) above the primary combustion zone in a coal-fired boiler. This upper-level firing creates a slightly fuel-rich zone. $\mathrm{NO}_{\mathrm{x}}$ produced in the lower region of the boiler is reduced in this "reburn" zone and converted to molecular nitrogen $\left(\mathrm{N}_{2}\right)$. Low-NO $\mathrm{N}_{\mathrm{x}}$ burners (LNBs) positioned in the primary combustion zone reduce the production of $\mathrm{NO}_{\mathrm{x}}$ by staging the burning process to lower the temperature and oxygen/fuel ratio during primary combustion. The combination of these two technologies is referred to as GR-LNB. The expected effect of adding a reburning stage to a wall-fired boiler equipped with LNBs was to lower $\mathrm{NO}_{\mathrm{x}}$ emissions by up to $70 \%$. In this project, GR was demonstrated with and without the use of flue gas recirculation (FGR).

The Clean Air Act, initially promulgated in 1970 and amended in 1977, established New Source Performance Standards (NSPS) for emissions of $\mathrm{SO}_{2}, \mathrm{NO}_{\mathrm{x}}$, and particulates, among other pollutants, 
from stationary coal-fired power plants. These regulations were made more stringent in the Clean Air Act Amendments (CAAA) of 1990. The GR-LNB process offers a potential means of meeting $\mathrm{NO}_{\mathrm{x}}$ emissions requirements of the CAAA as administered by the U.S. Environmental Protection Agency (EPA).

The objectives for this project were:

- $\quad$ To attain up to $70 \%$ reduction in $\mathrm{NO}_{\mathrm{x}}$ emissions from an existing wall-fired utility boiler firing low-sulfur coal

- $\quad$ To assess the impact of GR-LNB on boiler performance

The independent evaluation contained herein is based primarily on information from EER's Final Report dated July 1998 [11], as well as the other sources cited. In fulfillment of the cooperative agreement, EER also prepared a Guideline Manual [12] which provides an overview of the technology requirements for GR-LNB. 


\section{TECHNICAL AND ENVIRONMENTAL ASSESSMENT}

This project evaluates the technical and economic feasibility of controlling $\mathrm{NO}_{\mathrm{x}}$ emissions from a wallfired utility boiler by using GR in combination with LNBs. LNBs usually achieve 30-50\% $\mathrm{NO}_{\mathrm{x}}$ reduction, while GR usually achieves $50-60 \% \mathrm{NO}_{\mathrm{x}}$ reduction. Adding GR to a wall-fired boiler equipped with LNBs was expected to lower $\mathrm{NO}_{\mathrm{x}}$ emissions by up to $70 \%$. The benefits anticipated from the combined GR-LNB technology were low capital costs relative to other $\mathrm{NO}_{\mathrm{x}}$-reduction processes coupled with no adverse effects on boiler thermal performance. Although there have been several demonstrations of the separate GR and LNB technologies prior to this project, this CCT project was the first full-scale demonstration of the combined technologies.

\section{A. Process Description}

A schematic flow diagram of the GR-LNB process is shown in Figure 1. GR is a combustion modification process that reduces the amount of $\mathrm{NO}_{\mathrm{x}}$ formed in the boiler by creating a reducing zone (the reburn zone) above the primary combustion zone. LNBs are air-staged burners that reduce temperature and oxygen concentration during the combustion process and, thus, reduce the amount of $\mathrm{NO}_{\mathrm{x}}$ produced in the primary combustion zone. LNBs have become the technology of choice for meeting the mandates of the CAAA for Phase I, Group 1 boilers, i.e., dry-bottom wall-fired boilers and tangentially fired (T-fired) boilers.

\section{Gas Reburning (GR)}

For coal-fired boilers, GR involves injecting natural gas downstream of the existing burners to create a reducing or reburn zone to destroy $\mathrm{NO}_{\mathrm{x}}$. High furnace temperatures $\left(2,600^{\circ} \mathrm{F}\right)$ and adequate residence times are needed for efficient $\mathrm{NO}_{\mathrm{x}}$ reduction. Reburning is followed by the injection of burnout or overfire air (OFA) to complete the combustion of the reducing gases, mainly carbon monoxide (CO). The process is shown schematically in Figure 2. 
Reburn technology involves three zones in the furnace: (1) a primary combustion zone where coal is fired; (2) a reburn zone where additional fuel is added to create reducing conditions to convert the $\mathrm{NO}_{\mathrm{x}}$ produced in the primary zone to molecular nitrogen $\left(\mathrm{N}_{2}\right)$ and other reduced nitrogen species; and (3) a burnout zone to complete the combustion of the reducing gases produced in the reburn zone.

Each zone has a unique stoichiometric air ratio (ratio of air used to that theoretically required for complete combustion) as determined by the flow of primary fuel, burner air, natural gas, and OFA. FGR can be used to increase the momentum of the injected natural gas to improve furnace penetration and mixing; but because recirculated flue gas has a low oxygen content, FGR has only a minor impact on the reburn zone fuel requirement and the burnout zone air rate.

- $\quad$ Primary Combustion Zone--Coal is fired at a rate corresponding to $75-90 \%$ of the total heat input, under normal to low excess air conditions. The rate of $\mathrm{NO}_{\mathrm{x}}$ formation in this zone is reduced by about $10 \%$ because less fuel is fired (lower production of fuel $\mathrm{NO}_{\mathrm{x}}$ ), the heat release rate is lower (lower production of thermal $\mathrm{NO}_{\mathrm{x}}$ ), and, generally, the excess air level to the burners is reduced to lower the oxygen concentration (lower fuel and thermal $\mathrm{NO}_{\mathrm{x}}$ production).

- $\quad$ Reburn Zone--Reburn fuel (natural gas in this case, but coal and oil can also be used) injection creates a reducing (fuel-rich) region within which natural gas (mostly methane, $\mathrm{CH}_{4}$ ) breaks down to form hydrocarbon fragments $\left(\mathrm{CH}, \mathrm{CH}_{2}\right.$, etc.) that react with $\mathrm{NO}_{\mathrm{x}}$, producing reduced-nitrogen species (mainly $\mathrm{N}_{2}$ ). The optimum reburn zone stoichiometric ratio is around 0.90 . This is achieved by injecting natural gas at a rate corresponding to $10-25 \%$ of the total heat input, depending on the primary combustion zone excess air level. The lower this excess air, the lower the reburn fuel requirement. FGR is sometimes used as a carrier for the reburn fuel and/or to increase momentum and penetration into the furnace.

- Burnout Zone--OFA is injected downstream of the reburn zone to complete combustion of the reburn zone fuel gases. OFA is typically $20 \%$ of the total air flow. An overall excess air 
level of $15-25 \%$, depending on the primary fuel type, is normally maintained. The OFA injection rate is optimized for each specific application to minimize $\mathrm{CO}$ emissions and unburned carbon in the fly ash.

\section{Low-NO ${ }_{x}$ Burners (LNBs)}

LNBs reduce emissions of $\mathrm{NO}_{\mathrm{x}}$ by staging the mixing of coal and air. This results in a fuel-rich region for char combustion, longer flames, and lower peak flame temperatures. LNBs generally use dual air registers in parallel to delay the mixing of air with coal injected through a coal nozzle in the center of the burner. While LNBs reduce $\mathrm{NO}_{\mathrm{x}}$, they may result in higher levels of unburned carbon and higher emissions of $\mathrm{CO}$. These result from incomplete combustion which may occur from the staging of coal/air mixing. OFA is sometimes used to decrease unburned carbon and CO. LNBs do not affect the emissions of other species such as $\mathrm{CO}_{2}, \mathrm{SO}_{2}$, or particulates.

\section{B. Project Description}

The demonstration site was PSCo's Cherokee Station, located in Denver, CO. The Cherokee Station is PSCo's largest electric power generating station, comprised of four boilers that generate a total of about 775 MWe. GR-LNB was installed on Cherokee Unit 3, which was built by Babcock and Wilcox (B\&W) in 1962 and, therefore, did not have to meet NSPS as required under the CAAA for units constructed after 1971. Unit 3 is a 172-MWe gross (158 MWe net) balanced-draft, wall-fired boiler, originally equipped with conventional B\&W flare-type pulverized coal (PC) burners. The unit has 16 burners (four rows of four burners) located on the front wall of the furnace.

Coal is pulverized with four Riley Stoker No. 556 duplex drum pulverizers to a specified fineness of $70 \%$ passing 200 mesh and 50\% passing 50 mesh. Pulverized coal is conveyed by $160^{\circ} \mathrm{F}$ primary air to the burners and combusted with $600^{\circ} \mathrm{F}$ secondary air. After leaving the main furnace, flue gas passes over a secondary superheater, reheat superheater, primary superheater, economizer, and two rotary air preheaters. Particulate collection is achieved via a baghouse using fabric filters. 
The CCT demonstration project included replacing the existing burners with Foster Wheeler Controlled Flow/Split Flame LNBs and installing injection ports to accommodate GR. Natural gas reburn fuel was injected through a total of 16 injectors, eight on the front wall and eight on the rear wall. Ambient air was used to cool the gas injection nozzles when the GR system was not in operation. OFA at a temperature of approximately $600^{\circ} \mathrm{F}$ was withdrawn from two secondary air ducts and boosted from 2 in. of water to 12 in. of water by an OFA booster fan. The OFA was routed to six ports located on the front wall of the furnace. The OFA injectors were tilted down at an angle of $10^{\circ}$ to provide better penetration of the air into the furnace combustion gases and to increase residence time in the burnout zone to lower $\mathrm{CO}$ emissions.

For this project, the GR-LNB equipment was controlled by a Westinghouse Distributed Process Family system (WDPF). The WDPF provided integrated modulating control, sequential control, and data acquisition for a wide variety of system applications.

FGR was used initially to increase the momentum of the natural gas in an effort to achieve optimum penetration into the furnace cross section. However, during the course of the project (see Figure 3), it was found that FGR had a minimal effect on $\mathrm{NO}_{\mathrm{x}}$ emissions. Cherokee Unit 3 has a reburn zone residence time of half a second, which is sufficient to achieve $\mathrm{NO}_{\mathrm{x}}$ reduction without the need for FGR. Therefore, part way through the project the unit was modified as follows:

- $\quad$ The FGR system was removed.

- $\quad$ The natural gas injectors were redesigned to operate at higher pressures. This took advantage of the higher pressure at which the natural gas was available and increased the velocity of gas injection.

- $\quad$ The OFA ports were modified to provide higher jet momentum, air swirl, and velocity control. These modifications were designed to improve furnace lateral coverage and turbulence for air mixing with unburned fuel in the upper furnace. 
This modified configuration is referred to by EER as Second-Generation GR, and it provided CO control within acceptable limits at a lower natural gas usage level. Elimination of FGR benefitted the process by (1) reducing natural gas usage and (2) reducing capital cost. The reduction in natural gas usage reduced operating costs because of the natural gas/coal price differential. The reduced gas usage also reduced superheater attemperation water spray rates due to the decreased heat release in the upper part of the furnace.

The coal burned during this project was a low-sulfur (0.45 wt $\%)$ Colorado bituminous coal. Properties of this coal are given in Table 1.

\section{Project Results}

Field testing included parametric optimization studies, followed by one year of long-term testing. Baseline, uncontrolled $\mathrm{NO}_{\mathrm{x}}$ emissions at Cherokee Unit 3 were $0.73 \mathrm{lb} / 10^{6}$ Btu. Replacement of the original burners with low- $\mathrm{NO}_{\mathrm{x}}$ burners reduced $\mathrm{NO}_{\mathrm{x}}$ emissions to $0.46 \mathrm{lb} / 10^{6} \mathrm{Btu}$, a $37 \%$ reduction. While significant, this performance fell short of the target value of $45 \%$ reduction. The use of GR in combination with LNBs resulted in a further lowering of $\mathrm{NO}_{\mathrm{x}}$ emissions to an average of 0.25 $\mathrm{lb} / 10^{6} \mathrm{Btu}$, an overall reduction of $66 \%$. This level of reduction was achieved at a natural gas usage of $18 \%$ of the total heat input. At these conditions, GR achieved only a $45 \%$ reduction of the $\mathrm{NO}_{\mathrm{x}}$ reaching the reburn zone, which is on the low side of what is normally achieved with GR.

Following installation of the Second-Generation GR equipment and tune-up of the LNBs, the system achieved a $\mathrm{NO}_{\mathrm{x}}$ emissions rate of $0.26 \mathrm{lb} / 10^{6} \mathrm{Btu}$, a $64 \%$ overall reduction from baseline, at a natural gas reburn heat input of only $12.5 \%$. This version of GR-LNB offers improved economics, since the same degree of $\mathrm{NO}_{\mathrm{x}}$ emissions reduction is achieved with a significantly smaller consumption of natural gas, which is more expensive than coal on a Btu basis.

Figure 4 shows $\mathrm{NO}_{\mathrm{x}}$ emissions reduction during the test period. In both the first- and secondgeneration tests, the target level of $70 \%$ overall $\mathrm{NO}_{\mathrm{x}}$ reduction was reached, but only for short periods and with significantly higher gas heat inputs than required for the results discussed above. 
Thus, it is somewhat questionable to say that the performance objectives of the CCT project were achieved, as claimed in the EER Final Report and its companion Guideline Manual.

The variables studied in the demonstration of GR-LNB were: (a) primary combustion zone excess air level; (b) natural gas heat input as a fraction of the total heat input; (c) reburn zone air/fuel stoichiometric ratio; (d) FGR rate; (e) and OFA rate.

The importance of the primary zone stoichiometric ratio (SR) is shown by Figure 5. As the primary zone SR increases, so do $\mathrm{NO}_{\mathrm{x}}$ emissions. Another effect of higher primary zone SR is to increase the reburn fuel requirement. Since the reburn zone needs to be in a fuel rich situation, the more oxygen reaching the reburn zone, the more fuel that needs to be added to achieve fuel rich conditions. On the other hand if the primary SR is too low, the loss on injection (LOI) can be high and reduced sulfur compounds produced at these conditions can cause erosion of the boiler tubes. For this work, a SR in the range of 1.08-1.10 gave satisfactory results.

Figure 6 (First Generation GR) and Figure 7 (Second Generation GR) show the effect on $\mathrm{NO}_{\mathrm{x}}$ emissions of the percentage of the total heat input provided by natural gas. Better results were obtained as the natural gas rate increased, but benefits appear to level out somewhere in the range of $10-15 \%$ natural gas heat input. Figure 8 shows that good $\mathrm{NO}_{\mathrm{x}}$-reduction results can be achieved over a load factor range of $70-100 \%$.

Figure 9 (First Generation GR) and Figure 10 (Second Generation GR) show that the effect of total excess air, as indicated by the oxygen in the flue gas, is relatively small. This is not unexpected because total excess air tends to be set by the amount of overfire air, which should have relatively little effect on $\mathrm{NO}_{\mathrm{x}}$ emissions. The slight increase in $\mathrm{NO}_{\mathrm{x}}$ levels with increased excess air is probably attributed to some secondary $\mathrm{NO}_{\mathrm{x}}$ formation in the burnout zone. An important function of the burnout zone is to decrease CO concentration, so OFA rate needs to be high enough to achieve an acceptable $\mathrm{CO}$ emissions level. The effect of excess air on $\mathrm{NO}_{\mathrm{x}}$ reduction, unburned carbon, and $\mathrm{CO}$ emissions is shown in Table 2. As this table shows, both $\mathrm{CO}$ emissions and carbon-in-ash values are acceptable with furnace exit $\mathrm{O}_{2}$ levels of $4 \%$ or higher. 
The most important findings were:

- Increasing the fractional heat input in the reburn zone up to about $20 \%$ and decreasing the reburn zone stoichiometric ratio to about 0.9 have the strongest impact on $\mathrm{NO}_{\mathrm{x}}$ emissions.

- $\quad$ The $\mathrm{NO}_{\mathrm{x}}$ emissions reduction target level can be approached by operating with reburn gas heat input levels of only 10-13\%, using the Second Generation GR system (elimination of FGR and redesigned OFA injection).

\section{Boiler Impacts}

In the test program, GR-LNB operation was shown to have only minor impacts on boiler performance. The thermal performance parameters monitored were the flow rate, temperature and pressure of the steam, steam attemperation flow rate, total heat transferred to water/steam, gas side temperatures, thermal efficiency, and heat rate. The most significant impacts were observed in the boiler temperature profile, which changed because of the increased heat release in the upper furnace. Operational changes, such as increasing the steam attemperation flow rate, were required to maintain the thermal performance of the unit. Thermal efficiency was reduced slightly; thus heat rate was increased to a minor extent (about $0.8 \%$ ), as a result of two factors: (a) increased dry gas heat loss caused by higher economizer inlet temperatures, and (b) increased moisture in the flue gas caused by combusting natural gas, which has a higher hydrogen content than coal. Another boiler impact was a small amount of furnace slagging.

Regarding parasitic power requirements, there are offsetting effects. Increased power is required for the OFA fans. On the other hand, because of the decreased coal consumption, pulverizer power is reduced. The result is a slight decrease in auxiliary power requirements for GR-LNB. There was no measurable tube wear or reduction of baghouse efficiency. 
The GR-LNB project also produced some environmental effects. The use of lower carbon content natural gas to replace part of the coal feed provided a modest reduction (about 5\% at 13\% gas input) in emissions of $\mathrm{CO}_{2}$, a major greenhouse gas. As anticipated, $\mathrm{SO}_{2}$ and particulate emissions were reduced in proportion to the amount of coal feed replaced with natural gas.

\section{Award}

EPA, GRI, and DOE were the recipients of the Air \& Waste Management Association's 1997 J. Dean Sensenbaugh Award for their collaborative work in developing GR into a viable and commercial emissions-control option for utility and industrial power-generation boilers.

\section{E. Commercialization of the Technology}

Although this CCT project included both LNBs and GR, GR is the more novel of the two technologies because LNBs have been used extensively to meet CAAA $\mathrm{NO}_{\mathrm{x}}$ emissions limits. Therefore, the following discussion primarily concerns the commercialization of gas reburning. The progress in commercializing GR is evidenced by the installations discussed below.

In a separate Round 1 CCT project, GR was successfully demonstrated, along with sorbent injection (SI) for $\mathrm{SO}_{2}$ control, at City Water, Light and Power's (CWLP) Lakeside Unit 7 located at Springfield, Illinois, a 33-MWe (net) cyclone boiler, and at Illinois Power's Hennepin Unit 7 located at Hennepin, Illinois, a 71 MWe (net) T-fired boiler [8]. These demonstrations achieved about 60\% $\mathrm{NO}_{\mathrm{x}}$ reduction with 18-23\% gas heat input. Thus, the GR-SI CCT project successfully demonstrated $\mathrm{NO}_{\mathrm{x}}$ reduction on two types of boilers other than the wall-fired boiler tested at Cherokee. Hennepin Unit 1 is typical of T-fired boilers, which are also fired with PC but produce relatively low levels of $\mathrm{NO}_{\mathrm{x}}$ (on the order of 0.6-0.7 $\mathrm{lb} / 10^{6} \mathrm{Btu}$ ). Lakeside Unit 7 is typical of cyclone firing systems, which burn crushed coal and generate high levels of $\mathrm{NO}_{\mathrm{x}}$ (typically 1.0-2.0 lb/10 ${ }^{6} \mathrm{Btu}$ ). The success of controlling $\mathrm{NO}_{\mathrm{x}}$ emissions on three different boiler firing systems is a promising indication of the broad applicability of GR, although site-specific conditions must be taken into account when considering the applicability of GR-LNB. 
In addition, GR has been successfully applied on a 300-MWe T-fired boiler in Ukraine [6]. Reburning has also been used on a number of utility boilers ranging up to 800 MWe in Italy [9], and testing a GR installation on a 700-MWe wall-fired boiler of Scottish Power [7] is in progress. Japan had the earliest installations, but these are now idle because the stringent Japanese $\mathrm{NO}_{\mathrm{x}}$ emissions regulations can be satisfied only by post-combustion processes such as selective catalytic reduction (SCR).

Since conclusion of the Cherokee demonstration project, the GR-LNB system has been retained and operated by the host site. During the course of this project, a database was developed for future application of GR-LNB technology to control $\mathrm{NO}_{\mathrm{x}}$ emissions from wall-fired boilers. The technology is being commercialized by EER. EER has installed and started up GR systems on a glass furnace at an Anchor Glass factory, and on a 100-MWe (net) T-fired utility boiler at the Greenidge Station of New York State Electric and Gas (NYSEG). In addition, EER has recently been awarded contracts for GR retrofit installations on up to five large coal-fired cyclone boilers. These include the 330-MWe Unit 1 (startup in progress) of the Allen Fossil Station of TVA with options for Units 2 and 3 (330 MWe each), and the 200-MWe Unit 2 of the C.P. Crane Station of Baltimore Gas and Electric with an option for Unit 1 (also $200 \mathrm{MWe}$ ). These new projects would increase EER's U.S. reburning installations to 11 with a total capacity of 1700 MWe. Ultimately, $\mathrm{NO}_{\mathrm{x}}$ emissions regulations will be the driving force for GR commercialization.

$\mathrm{B} \& \mathrm{~W}$ has installed GR for $\mathrm{NO}_{\mathrm{x}}$ control on an electric utility-size coal-fired industrial cyclone boiler (40 MWe equivalent) at Kodak Park, Rochester NY. This commercial installation was also supported by GRI as part of its "Validation and Deployment of Gas Injection Technologies" project. Fifty percent $\mathrm{NO}_{\mathrm{x}}$ reduction was achieved.

ABB Combustion Engineering has installed and tested a commercial "close-coupled" gas reburn retrofit on a 200-MWe gas- and oil-fired boiler at Long Island Electric Company's E.G. Barrett Station. This work was also supported by Empire State Electric Energy Research Corporation 
(ESEERCO), EPRI, and GRI. A reduction in $\mathrm{NO}_{\mathrm{x}}$ emissions of 50\% was achieved with either gas reburning or staged air combustion.

\section{Size Considerations}

Since GR is an injection technology, the issue of scale-up for adequate gas jet penetration, coverage, and mixing with the bulk flue gases still needs to be evaluated on larger-scale applications. Based on experience in other countries and ongoing U.S. projects using GR for $\mathrm{NO}_{\mathrm{x}}$-emissions control, the feasibility of applying GR technology to larger units appears to be promising, and, so far, no upper size limitations for GR applications have been encountered. The minimum size is probably close to that of CWLP's Lakeside Unit 7, based on requirements of sufficient residence time at the appropriate temperatures in the reburn zone. There are no minimum or maximum capacity limitations on LNB installations. 


\section{MARKET ANALYSIS}

\section{A. Potential Markets}

The driving force for the use of GR-LNB to control $\mathrm{NO}_{\mathrm{x}}$ emissions from coal-fired utility boilers stems from Titles I and IV of the CAAA. Title IV (acid rain) regulations for Phase I, Group 1 boilers (dry-bottom wall-fired and T-fired) became effective January 1, 1996, followed by regulations for Phase II, Group 1 and Phase II, Group 2 boilers (cyclone, cell burner, wet bottom, dry bottom vertical, stoker, and fluidized bed firing systems), which will become effective January 1, 2000. The Title IV regulations for utility boiler $\mathrm{NO}_{\mathrm{x}}$ emissions are shown in Table 3.

Title I ozone nonattainment regulations are also expected to become a significant driving force for utility boiler $\mathrm{NO}_{\mathrm{x}}$ control. EPA has recently promulgated a rule that would apply stringent $\mathrm{NO}_{\mathrm{x}}$ controls to 22 states and the District of Columbia. This could result in a large number of coal-fired utility boilers having to meet $\mathrm{NO}_{\mathrm{x}}$ emissions limits as low as $0.15 \mathrm{lb} / 10^{6} \mathrm{Btu}$.

From the perspective of the potential market for GR applications, the cyclone boilers in Group 2 represent the best opportunity (in addition to the existing potential for Group 1 boilers), because the less expensive LNB and staged fuel-firing options seem to provide an appropriate solution for cell burner and other wet-bottom boilers, respectively. There are about 75 cyclone boilers in the United States, having a total capacity of about 20,000 MWe; these boilers exceed the $\mathrm{NO}_{\mathrm{x}}$ emissions standard of $0.86 \mathrm{lb} / 10^{6}$ Btu under Title IV, Phase II. It should be noted that virtually any fossil fuel can be used for reburning, so GR would not have all of the reburning market to itself. For example, coal reburning, which is a demonstrated technology, has higher capital and lower operating costs than GR, so the choice is site-specific.

The most significant market factors affecting the application of GR are the availability and price of natural gas. Availability impacts the capital cost, while the price of natural gas (or the gas/coal price differential) is of critical importance to the operating cost. 


\section{B. Economic Assessment of Utility Boiler Applications}

\section{GR-LNB Costs}

The EER Final Report [11] includes preliminary economics (-10\%/ +15\% accuracy) for the GR-LNB technology. The economics assume a hypothetical 300-MWe (net) wall-fired boiler retrofit burning $3 \mathrm{wt} \%$ sulfur coal, with a $10,000 \mathrm{Btu} / \mathrm{kWh}$ heat rate, a capacity factor of $65 \%$, and $12.5 \%$ gas heat input. It is assumed that access to a natural gas pipeline is available onsite, thereby eliminating the need to bring gas to the power plant. Providing a pipeline could add significantly to the cost of a GR project, depending on the distance involved.

The economics for GR-LNB are presented in Table 4. The estimated capital cost is $\$ 26 / \mathrm{kWe}$, of which GR contributes $\$ 12 / \mathrm{kWe}$ and LNB contributes $\$ 14 / \mathrm{kWe}$. Natural gas is priced at $\$ 2.47 / 10^{6}$ Btu and coal at $\$ 1.47 / 10^{6}$ Btu, i.e., a cost differential between gas and coal of $\$ 1.00 / 10^{6}$ Btu. To account for the slight loss in overall boiler efficiency, the amount of fuel fired is increased by $0.8 \%$ compared with baseline operation. This incremental fuel is priced at $\$ 1.60 / 10^{6} \mathrm{Btu}$, which is the weighted price of coal and gas in the proportions used. The economics include an allowance for reduced $\mathrm{SO}_{2}$ emissions resulting from the substitution of natural gas (containing no sulfur) for a portion of the coal feed. EER credits this reduction in $\mathrm{SO}_{2}$ at $\$ 95 /$ ton in the emissions trading market. Based on these assumptions, the levelized cost of the GR-LNB process is $\$ 1,027 /$ ton $\mathrm{NO}_{\mathrm{x}}$ removed (current dollar basis) or \$786/ton (constant dollar basis). Figure 11 shows the effect of several operating variables on the cost of $\mathrm{NO}_{\mathrm{x}}$ reduction.

\section{Comparison with Other Technologies}

The EER Final Report includes an economic comparison of GR-LNB with other technologies, using information from a separate study supported by the EPA. Table 5 compares capital and levelized costs for GR-LNB with those for coal reburning, selective noncatalytic reduction (SNCR) and SCR at a power plant capacity of $400 \mathrm{MWe}$, again assuming a $\$ 1 / 10^{6} \mathrm{Btu}$ gas/coal price differential. GRLNB appears to be the most expensive of the technologies considered, but the comparison is limited 
to processes offering modest levels of $\mathrm{NO}_{\mathrm{x}}$ removal, i.e., 35-65\%. The economics of SCR would be significantly different at its maximum $\mathrm{NO}_{\mathrm{x}}$-reduction capability of 80-90\%. 


\section{CONCLUSIONS}

The results from the GR-LNB technology demonstrated by EER at Cherokee Station approached, but did not meet, the CCT project's performance objectives. Acceptable unit operability was achieved with both the GR and the LNB components.

The gas reburning component of the process appears to be broadly applicable for retrofit $\mathrm{NO}_{\mathrm{x}}$ control to most utility boilers and, in particular, to wet-bottom cyclone boilers, which are high $\mathrm{NO}_{\mathrm{x}}$ emitters and are difficult to control (LNB technology is not applicable to cyclone boilers). GR-LNB can reduce $\mathrm{NO}_{\mathrm{x}}$ to mandated emissions levels under Title IV of the CAAA without significant, adverse boiler impacts. The GR-LNB process may be applicable to boilers significantly larger than the demonstration unit, provided there is adequate dispersion and mixing of injected natural gas.

Major results of the demonstration project are summarized as follows:

- $\quad \mathrm{NO}_{\mathrm{x}}$-emissions reductions averaging $64 \%$ were achieved with $12.5 \%$ gas heat input in longterm tests on a 158-MWe (net) wall-fired unit. The target reduction level of $70 \%$ was achieved only on a short-term basis with higher gas consumption.

- The thermal performance of coal-fired boilers is not significantly affected by GR-LNB. Convective section steam temperatures can be controlled within acceptable limits. Thermal efficiency is decreased by a small amount (about $0.8 \%$ ), because of increased dry gas loss and higher moisture in the flue gas as a result of the GR process.

- $\quad$ Furnace slagging and convective section fouling can be adequately controlled.

- Because of the higher hydrogen/carbon $(\mathrm{H} / \mathrm{C})$ ratio of natural gas compared with coal, use of the GR process results in a modest reduction in $\mathrm{CO}_{2}$ emissions. $\mathrm{SO}_{2}$ and particulate emissions are reduced in direct proportion to the fraction of heat supplied by natural gas. 


\section{REFERENCES}

1. "Evaluation of Gas Reburning and Low- $\mathrm{NO}_{\mathrm{x}}$ Burners on a Wall-Fired Boiler," Comprehensive Report to Congress, Clean Coal Technology Demonstration Program, a project proposed by Energy and Environmental Research Corporation to the U.S. Department of Energy, Office of Fossil Energy, September 1990.

2. T.M. Sommer, C.C. Hong, and H.M. Moser (EER) and H.J. Ritz (DOE), "Integrating Gas Reburning with Low $\mathrm{NO}_{\mathrm{x}}$ Burners," First Annual Clean Coal Technology Conference, Cleveland, OH, September 1992.

3. C.C. Hong et al. (EER) and H.J. Ritz (DOE), "Gas Reburning and Low-NO $\mathrm{N}_{\mathrm{x}}$ Burners on a Wall-Fired Boiler," Second Annual Clean Coal Technology Conference, Atlanta, GA, September 1993.

4. A. Sanyal et al. (EER) and H.J. Ritz (DOE), "Advanced $\mathrm{NO}_{\mathrm{x}}$ Control Technologies," Tenth Annual International Pittsburgh Coal Conference, Pittsburgh, PA, September 1993.

5. R.T. Keen et al. (EER), H.J. Ritz (DOE), J.M. Pratapas (GRI), and E.G. Rindahl (PSCo), "Gas Reburning in Tangentially, Wall-, and Cyclone-Fired Boilers $\mathrm{A}$ An Introduction to Second-Generation Gas Reburning," Third Annual Clean Coal Technology Conference, Chicago, IL, September 1994.

6. A. Tumanovsky, "Reduction of $\mathrm{NO}_{\mathrm{x}}$ Emissions by Reburning Process of Gas/Oil and Coal Boilers," Proceedings of the International Gas Reburn Technology Workshop, Appendix D, Gas Research Institute, Malmo, Sweden, February 1995.

7. J. Rhine, "The Demonstration of Gas Reburning at Longannet," Proceedings of the International Gas Reburn Technology Workshop, Appendix D, Gas Research Institute, Malmo, Sweden, February 1995. 
8. B. Folsom et al., "Three Gas Reburning Field Evaluations: Final Results and Long-term Performance," EPRI/EPA 1995 Joint Symposium on Stationary Combustion $\mathrm{NO}_{\mathrm{x}}$ Control, Book 4, Kansas City, MO, May 1995.

9. G. De Michele et al., "Development and Industrial Application of Oil Reburning for $\mathrm{NO}_{\mathrm{x}}$ Emission Control in Utility Boilers," EPRI/EPA 1995 Joint Symposium on Stationary Combustion $\mathrm{NO}_{\mathrm{x}}$ Control, Book 4, Kansas City MO, May 1995.

10. B. Folsom et al. (EER) and H.J. Ritz (DOE), "Demonstration of Gas Reburning-Low NO $_{\mathrm{x}}$ Burner Technology for Cost Effective $\mathrm{NO}_{\mathrm{x}}$ Emission Control," Fourth Annual Clean Coal Technology Conference, Denver, CO, September 1995.

11. Energy and Environmental Research Corporation, "Evaluation of Gas Reburning and Low$\mathrm{NO}_{\mathrm{x}}$ Burners on a Wall-Fired Boiler," Final Report, July 1998.

12. Energy and Environmental Research Corporation, "Evaluation of Gas Reburning and Low$\mathrm{NO}_{\mathbf{x}}$ Burners on a Wall-Fired Boiler," Guideline Manual, July 1998. 
Table 1. Properties of Coal Used in GR-LNB Tests

Coal Source: Colorado Bituminous

\begin{tabular}{|l|r|}
\hline Proximate Analysis, wt\% & \\
\hline Fixed Carbon & 45.34 \\
\hline Volatile Matter & 34.80 \\
\hline Moisture & 10.32 \\
\hline Ash & 9.54 \\
\hline Total & 100.00 \\
\hline Ultimate Analysis, wt\% & \\
\hline Carbon & 64.23 \\
\hline Hydrogen & 4.46 \\
\hline Nitrogen & 1.51 \\
\hline Sulfur & 0.45 \\
\hline Oxygen & 9.54 \\
\hline Moisture & 10.19 \\
\hline Ash & 9.62 \\
\hline Total & 100.00 \\
\hline Higher Heating Value, Btu/lb & 11,268 \\
\hline
\end{tabular}


Table 2. Effect of Excess Air on $\mathrm{NO}_{\mathrm{x}}$ Reduction, Unburned Carbon, and CO Emissions

\begin{tabular}{|l|c|c|c|}
\hline Furnace exit $\mathbf{O}_{\mathbf{2}}, \boldsymbol{\%}$ & $\mathbf{3}$ & $\mathbf{4}$ & $\mathbf{5}$ \\
\hline $\mathbf{N O}_{\mathbf{x}}, \mathbf{l b} / \mathbf{1 0} \mathbf{6}$ Btu & & & \\
\hline Baseline & 0.68 & 0.77 & 0.86 \\
\hline LNB & 0.42 & 0.49 & 0.54 \\
\hline Reduction, \% & 38 & 36 & 37 \\
\hline Carbon-in-ash, \% & & & \\
\hline Baseline & 5 & 5 & 4 \\
\hline LNB & 8 & 5 & 2 \\
\hline CO, ppm & & & \\
\hline Baseline & $<300$ & $<50$ & $<50$ \\
\hline LNB & $<1000$ & $<500$ & $<100$ \\
\hline
\end{tabular}


Table 3. Title IV NO Emissions Limits

$\mathrm{lb} / 10^{6} \mathrm{Btu}$

\begin{tabular}{|l|c|c|}
\hline Phase & I & II \\
\hline Compliance Date & January 1, 1996 & January 1, 2000 \\
\hline Group 1 Boilers & & 0.46 \\
\hline Dry Bottom Wall-Fired & 0.50 & 0.40 \\
\hline T-fired & 0.45 & 0.84 \\
\hline Group 2 Boilers & NA & 0.86 \\
\hline $\begin{array}{c}\text { Wet Bottom Wall-Fired } \\
>\text { 65 MWe }\end{array}$ & NA & 0.80 \\
\hline $\begin{array}{c}\text { Cyclone-Fired } \\
>\text { 155 MWe }\end{array}$ & NA & 0.68 \\
\hline Vertically Fired & NA & Exempt \\
\hline Cell Burner & NA & Exempt \\
\hline Fluidized Bed & NA & \\
\hline Stoker & & \\
\hline
\end{tabular}

$----$

$\mathrm{NA}=$ Not applicable 
Table 4. Summary of Performance and Cost Data 1996 Dollars

Coal Properties

Higher heating value (HHV)

$\frac{\text { Units }}{\mathrm{Btu} / \mathrm{lb}} \quad \frac{\text { Value }}{12,000}$

Power Plant Attributes With Controls

Plant capacity, net

$\begin{array}{cr}\text { MWe } & 300 \\ 10^{9} \mathrm{kWh} / \mathrm{yr} & 1.71 \\ \% & 65 \\ 10^{6} \text { tons } / \mathrm{yr} & 0.68\end{array}$

$\mathrm{NO}_{\mathrm{x}}$-Emissions-Control Data

Removal efficiency

Emissions standard (Title IV)

Emissions without GR-LNB

$\begin{array}{cr}\% & 64.0 \\ \mathrm{lb} / 10^{6} \mathrm{Btu} & 0.46 \\ \mathrm{lb} / 10^{6} \mathrm{Btu} & 0.73 \\ \mathrm{lb} / 10^{6} \mathrm{Btu} & 0.26 \\ \text { tons/yr } & 3990\end{array}$

$\mathrm{NO}_{\mathrm{x}}$ removed

$\$ / \mathrm{kW}$

26

$\underline{\text { Total Capital Requirement }}$

\begin{tabular}{ccc}
$\begin{array}{c}\text { Levelization } \\
\text { Factor [a] }\end{array}$ & $\underline{\text { mills/kWh }}$ & $\begin{array}{c}\text { \$/ton } \\
\text { NO }_{x} \text { removed }\end{array}$ \\
\cline { 2 - 3 } 0.160 & 0.73 & \\
1.314 & 0.25 & \\
1.314 & $\underline{1.79}$ & $\underline{767}$ \\
& 2.77 & 1187 \\
1.314 & $\underline{(0.37)}$ & $\underline{(160)}$ \\
& 2.40 & 1027 \\
& & \\
0.124 & 0.57 & 244 \\
1.000 & 0.19 & 81 \\
1.000 & $\underline{1.36}$ & $\underline{583}$ \\
1.000 & $\frac{(0.28)}{2.12}$ & $\underline{(122)}$ \\
& 1.84 & 786
\end{tabular}

Levelized Cost, Current \$

Capital charge

Fixed O\&M

Variable O\&M

Total

$\mathrm{SO}_{2}$ credits, $\$ 95 /$ ton

Total with $\mathrm{SO}_{2}$ credits

Levelized Cost, Constant \$

Capital charge

0.124

244

Fixed O\&M

1.000

Variable O\&M

$\underline{583}$

Total

$\mathrm{SO}_{2}$ credits, $\$ 95 /$ ton

$(0.28)$

786

Total with $\mathrm{SO}_{2}$ credits 
Table 5. Comparison of Economics

Constant 1996 Dollars

300-MWe Plant Capacity

\begin{tabular}{|l|c|c|c|}
\hline \multicolumn{1}{|c|}{ Technology } & NO $_{\mathbf{x}}$ Reduction, \% & Capital Cost, \$/kWe & $\begin{array}{c}\text { Levelized Cost, } \\
\text { \$/ton of } \mathbf{N O}_{\mathbf{x}} \\
\text { Removed }\end{array}$ \\
\hline GR Only & 60 & 12 & 527 \\
\hline LNB Only & 45 & 14 & 227 \\
\hline $\begin{array}{l}\text { GR-LNB (Second } \\
\text { Generation) }\end{array}$ & 64 & 26 & 786 \\
\hline Coal Reburning & 50 & 28 & 592 \\
\hline SNCR & 35 & 9 & 700 \\
\hline SCR & 50 & 44 & 575 \\
\hline
\end{tabular}




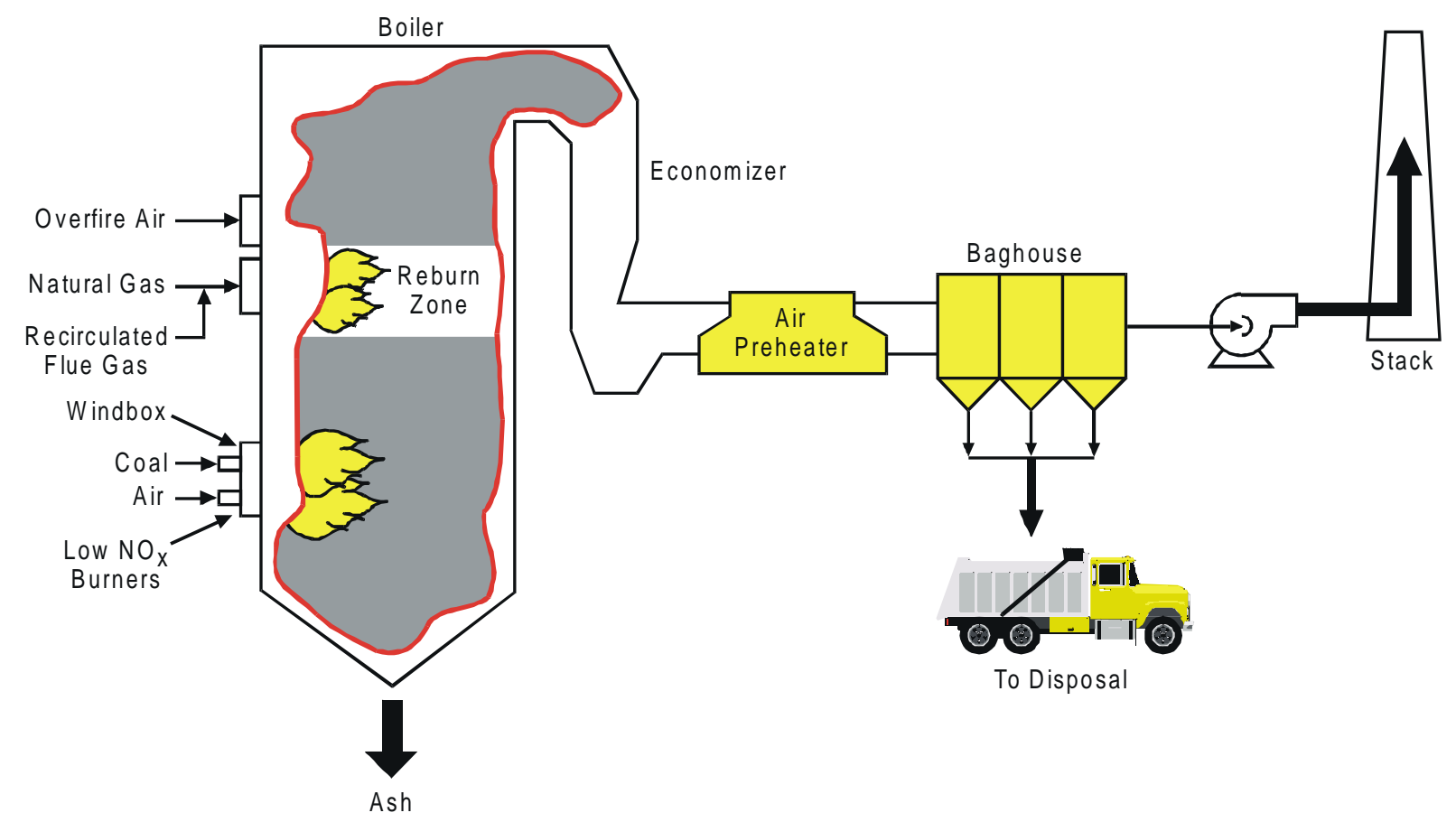

Figure 1. Schematic Flowsheet of GR-LNB Process 


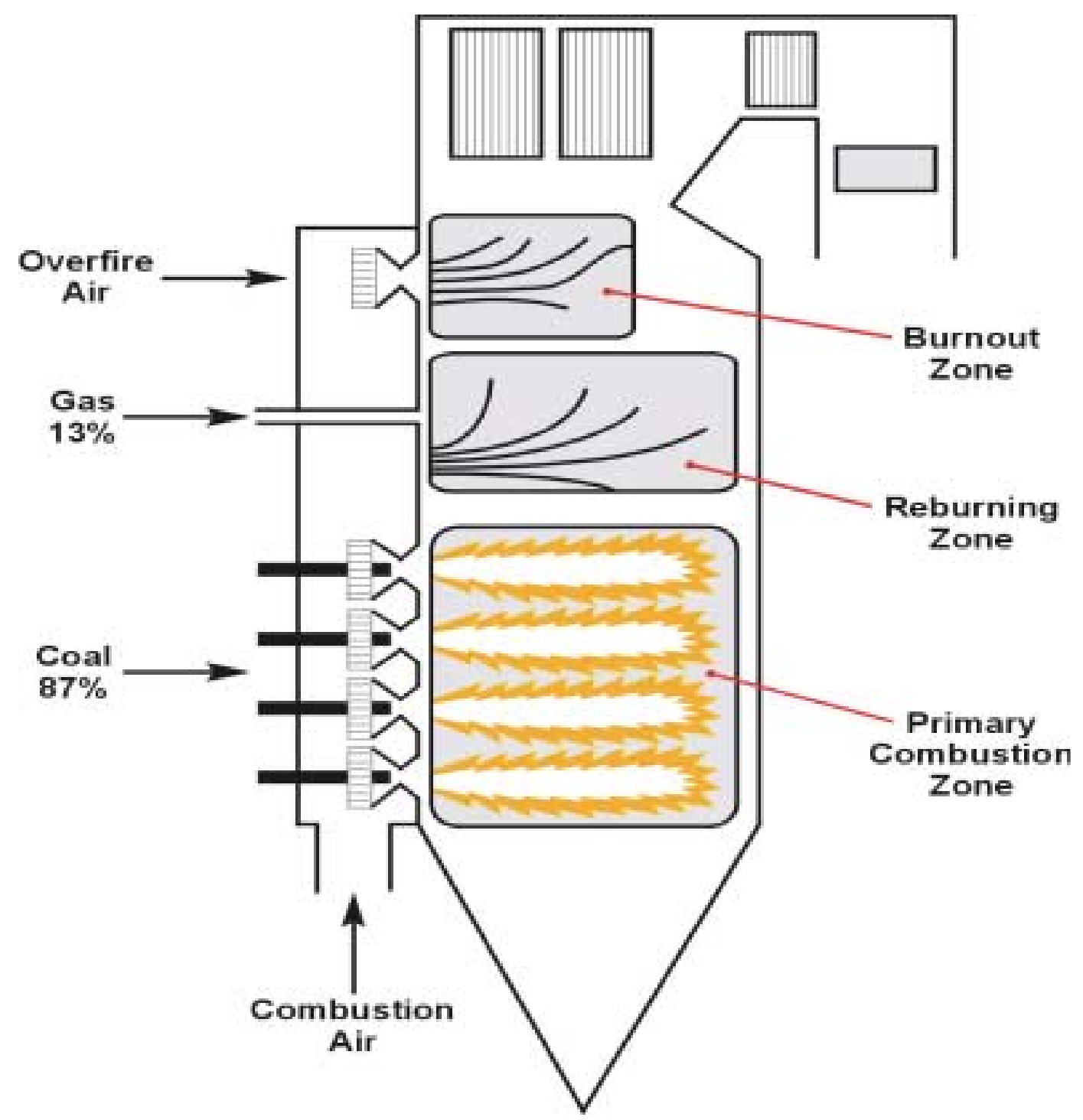

Figure 2. Schematic Flowsheet of Gas Reburning System 


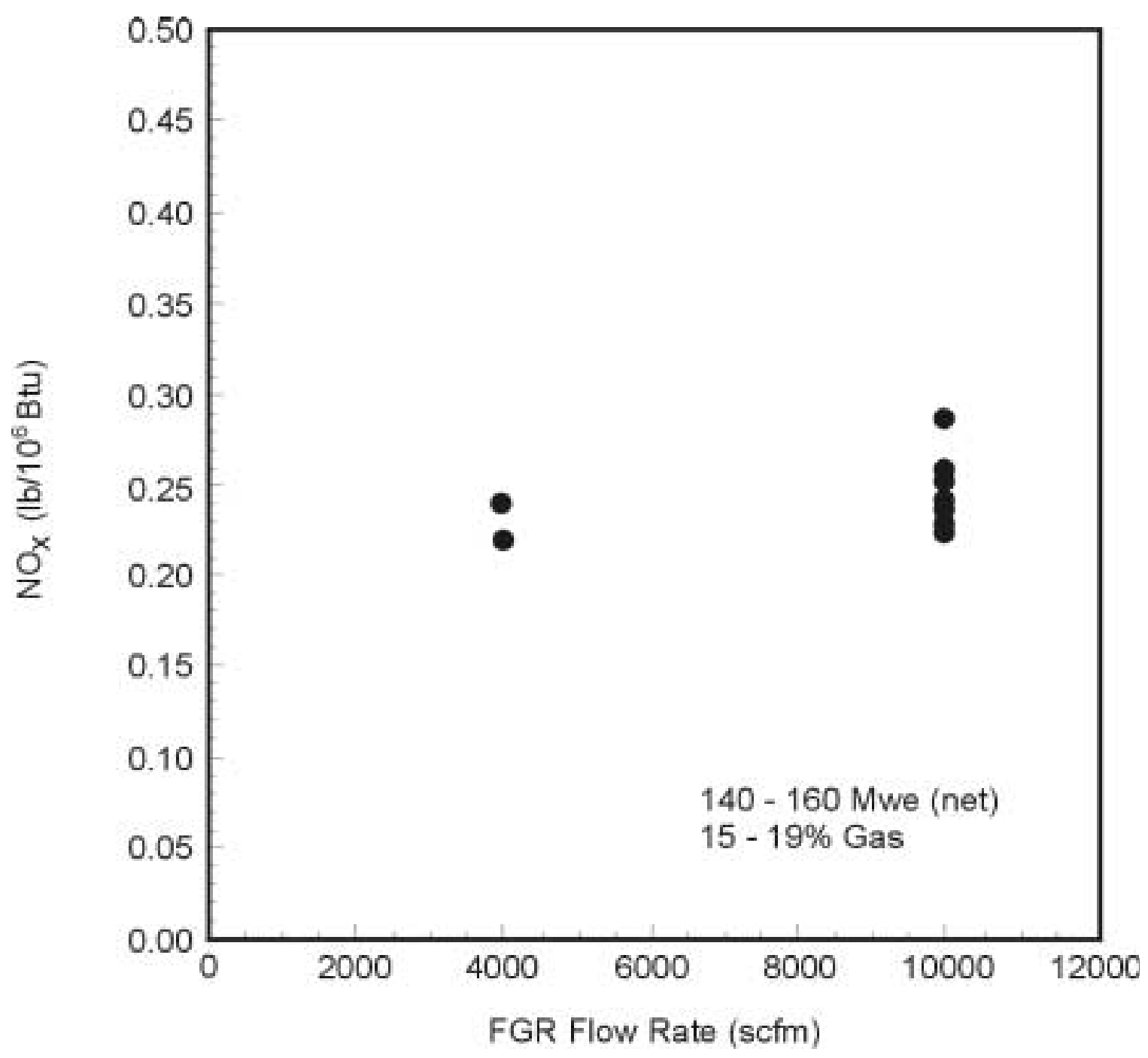

Figure 3. Effect of FGR Flow Rate on $\mathrm{NO}_{\mathrm{x}}$ Emissions, First-Generation GR-LNB 


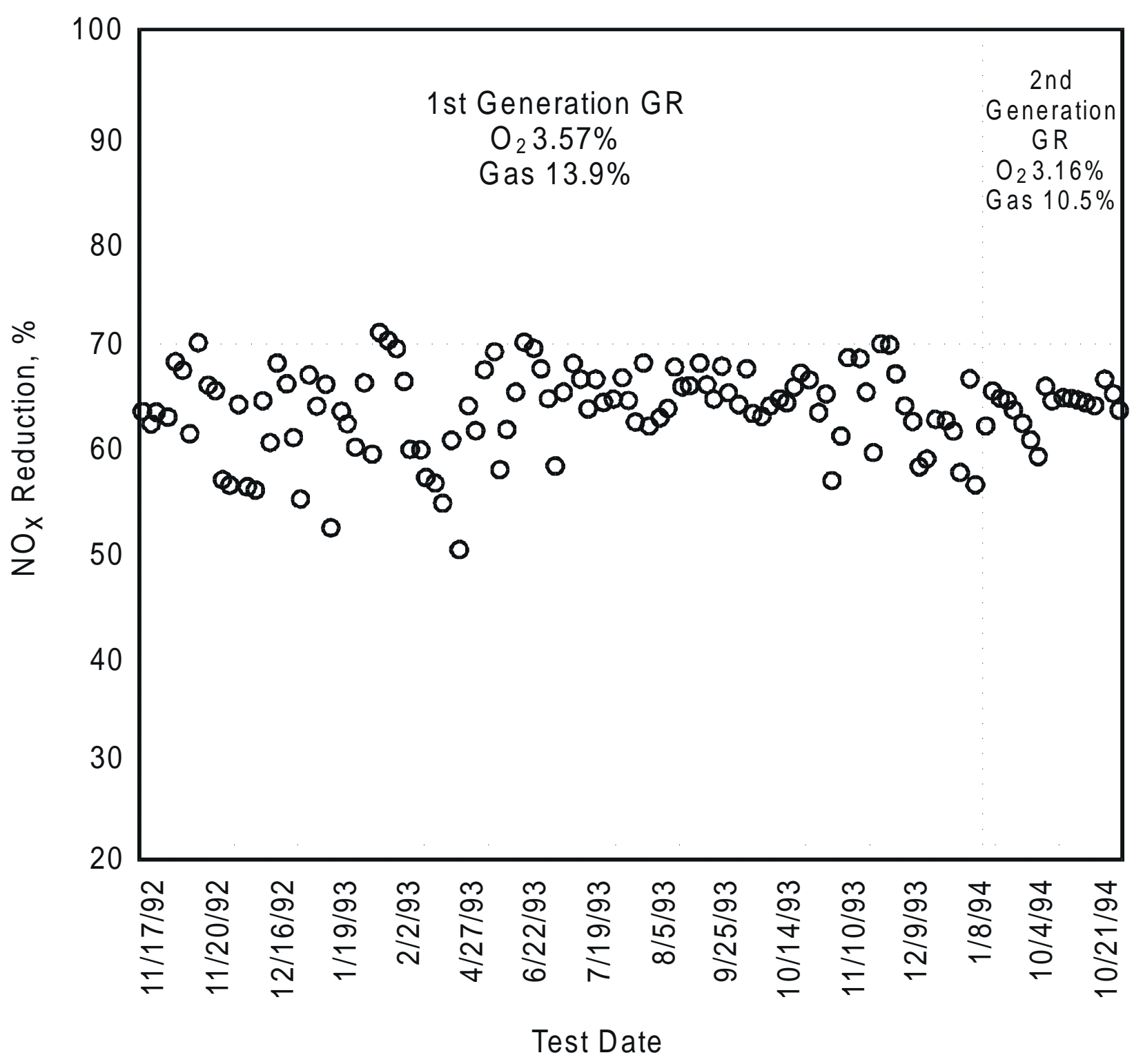

Figure 4. $\mathrm{NO}_{\mathrm{x}}$-Reduction Performance 


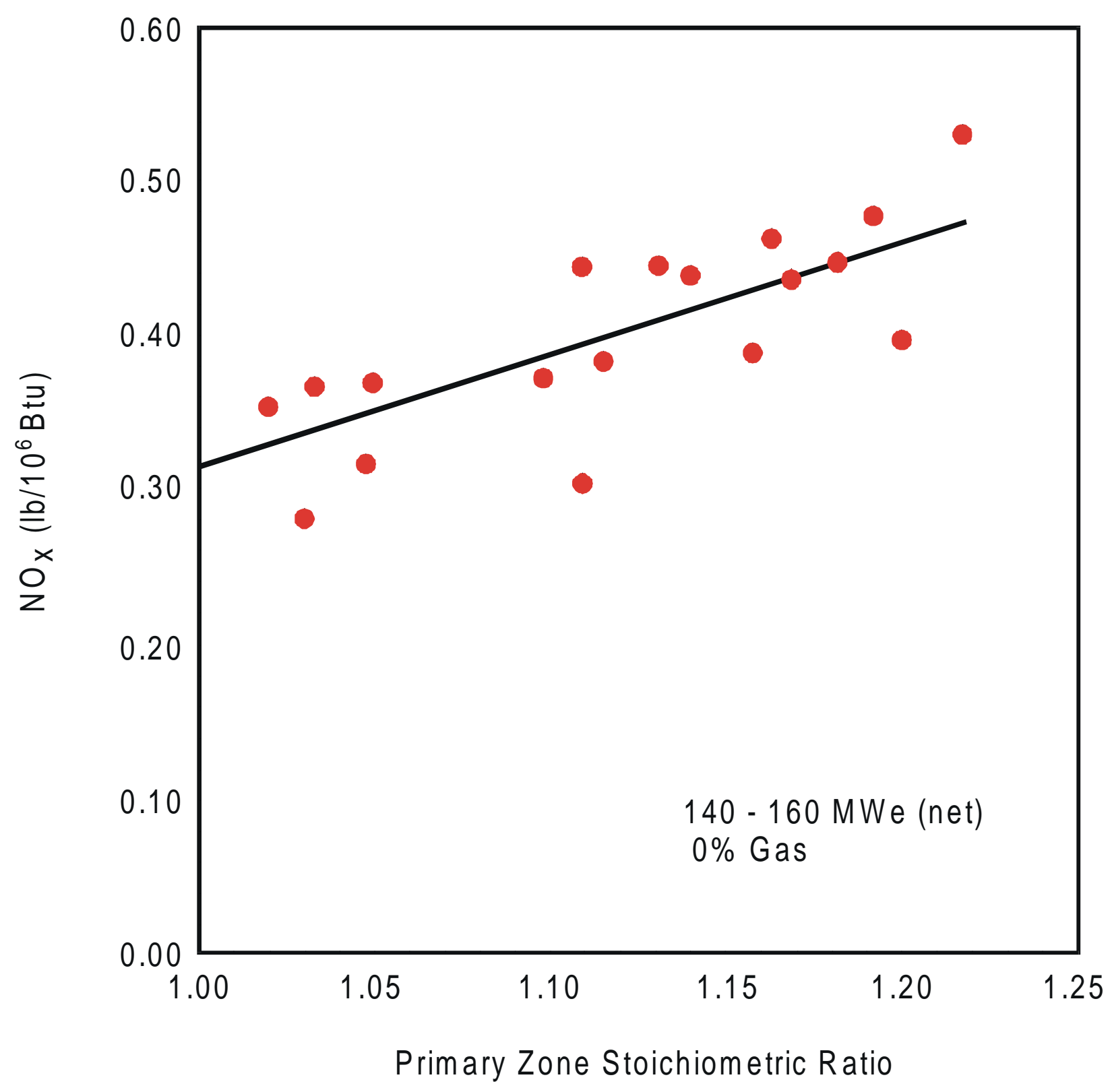

Figure 5. Effect of Primary Zone Stoichiometric Ratio on $\mathrm{NO}_{\mathrm{x}}$ Emissions, First-Generation GR 


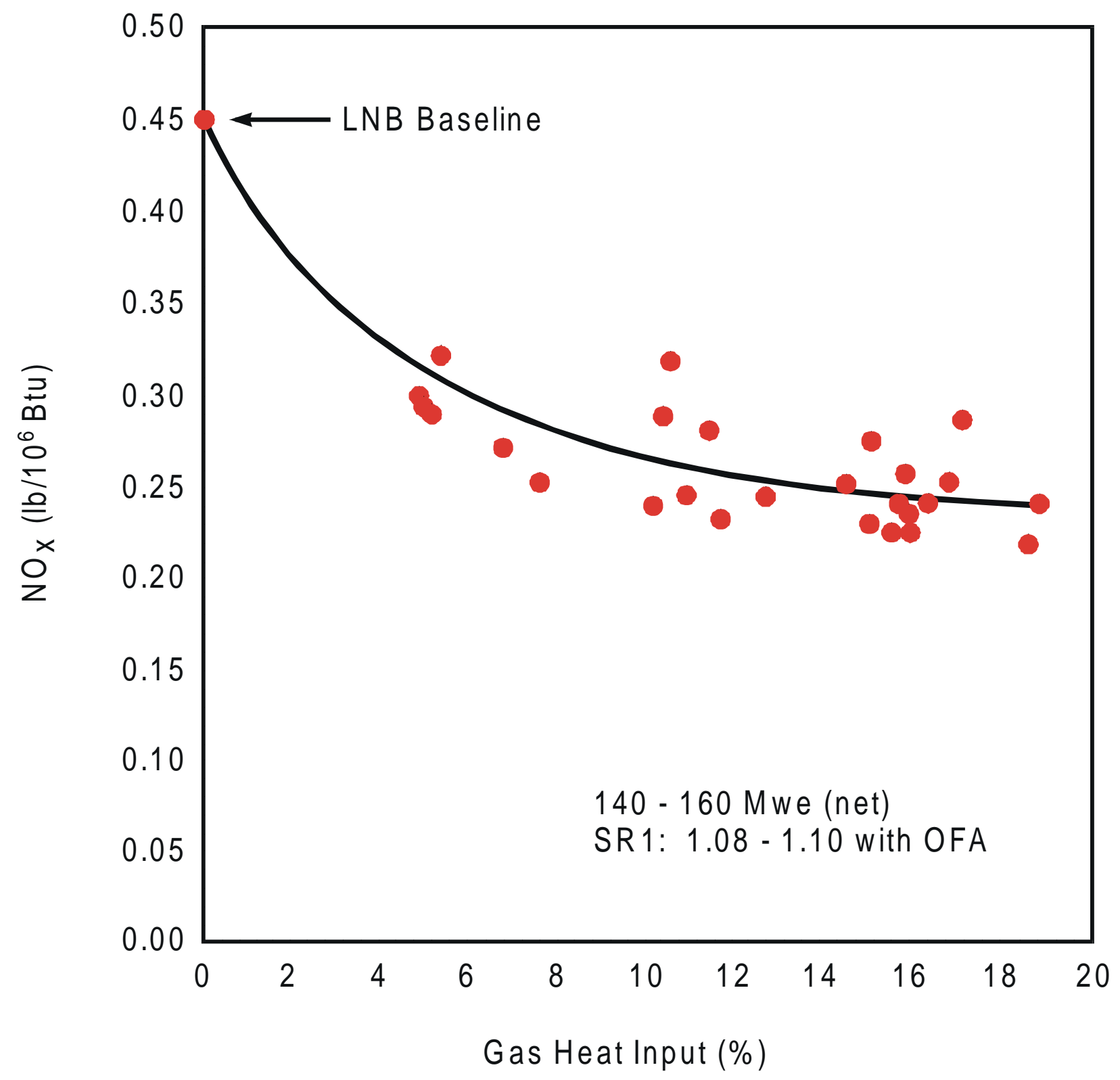

Figure 6. Effect of Gas Heat Input on $\mathrm{NO}_{\mathrm{x}}$ Emissions, First-Generation GR 


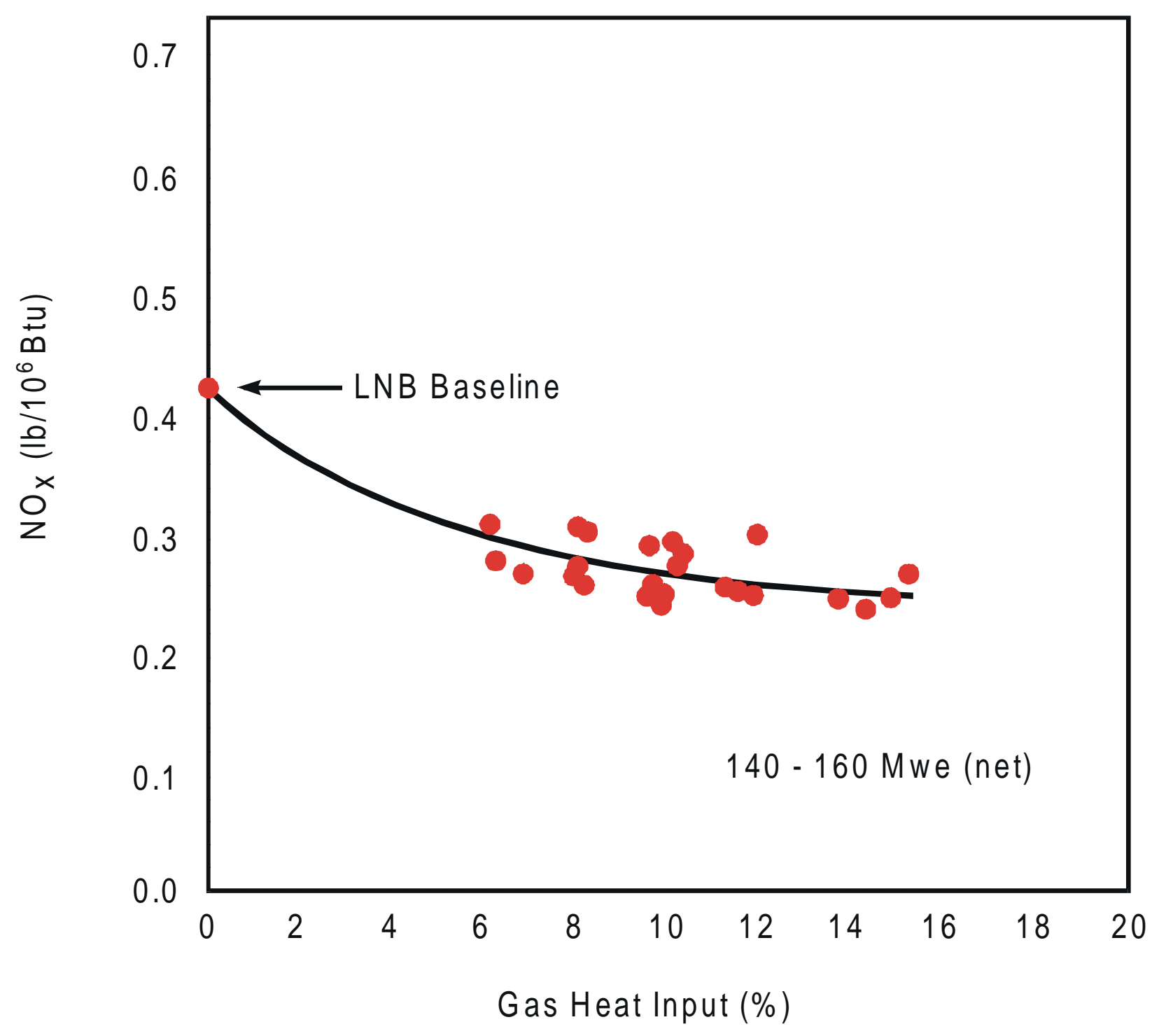

Figure 7. Effect of Gas Heat Input on $\mathrm{NO}_{\mathrm{x}}$ Reduction, Second-Generation GR 


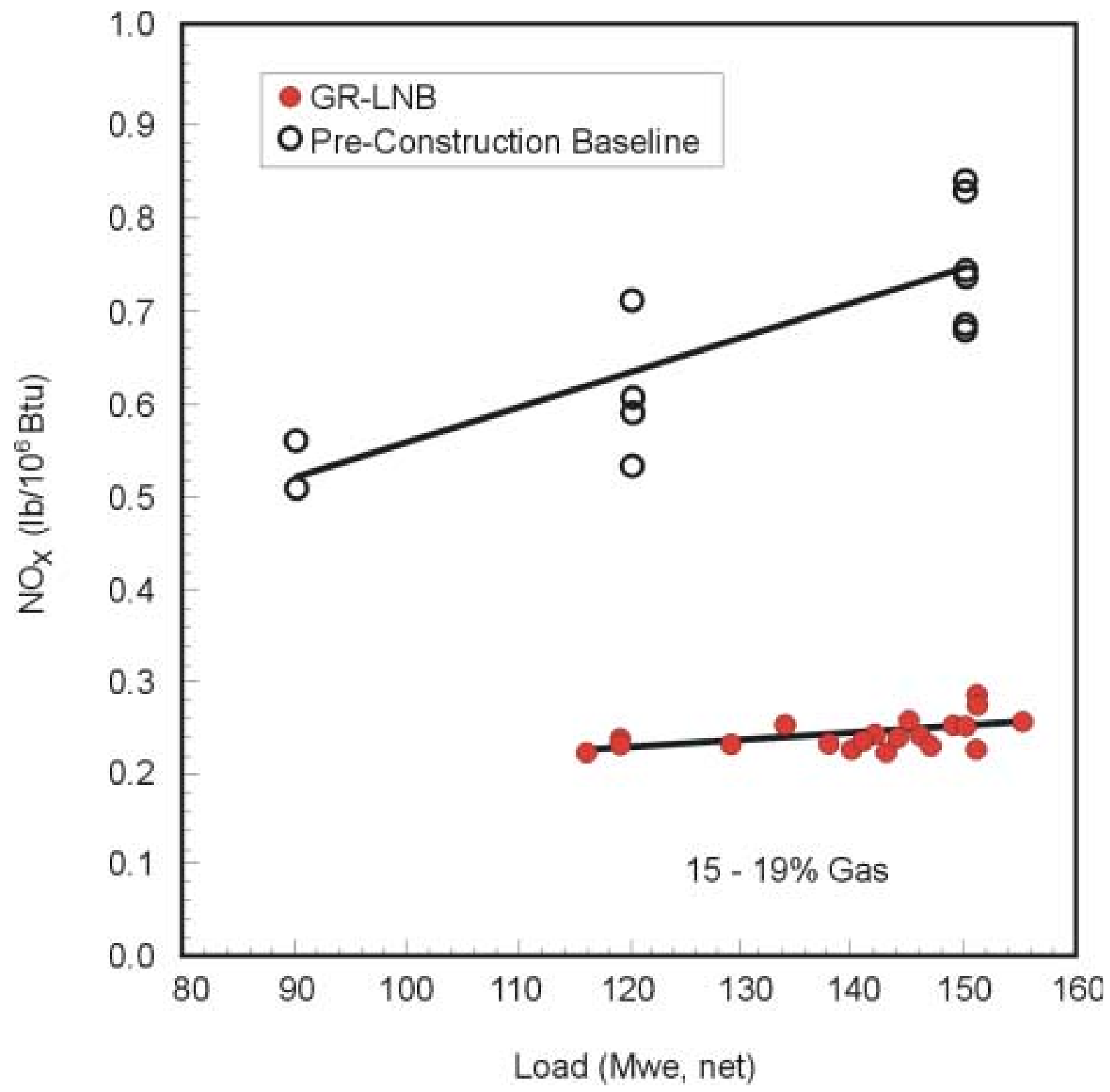

Figure 8. Effect of Load on $\mathrm{NO}_{\mathrm{x}}$ Reduction, First-Generation GR 


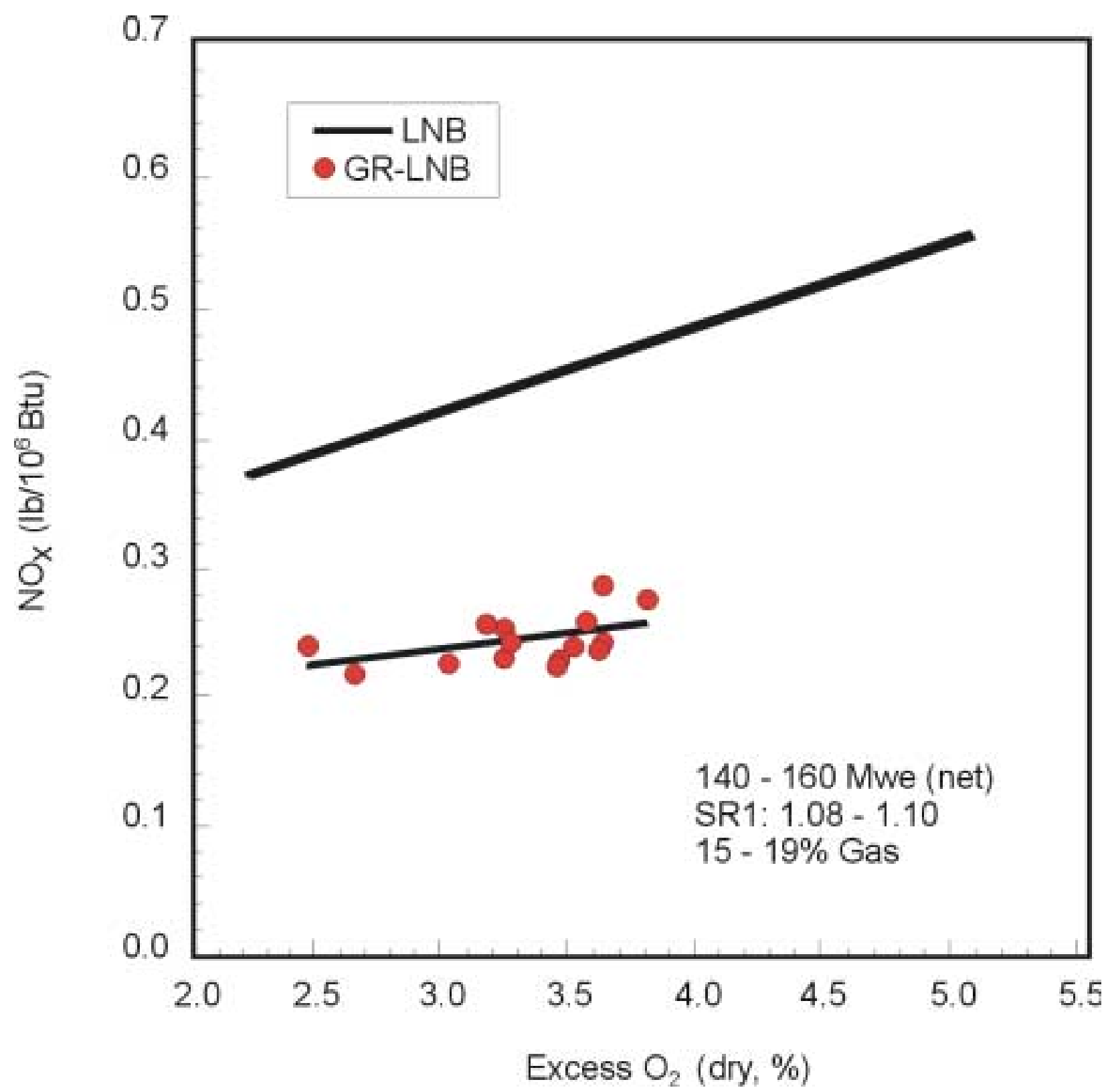

Figure 9. Effect of Exit Flue Gas $\mathrm{O}_{2}$ Concentration on $\mathrm{NO}_{\mathrm{x}}$ Emissions, First-Generation GR 


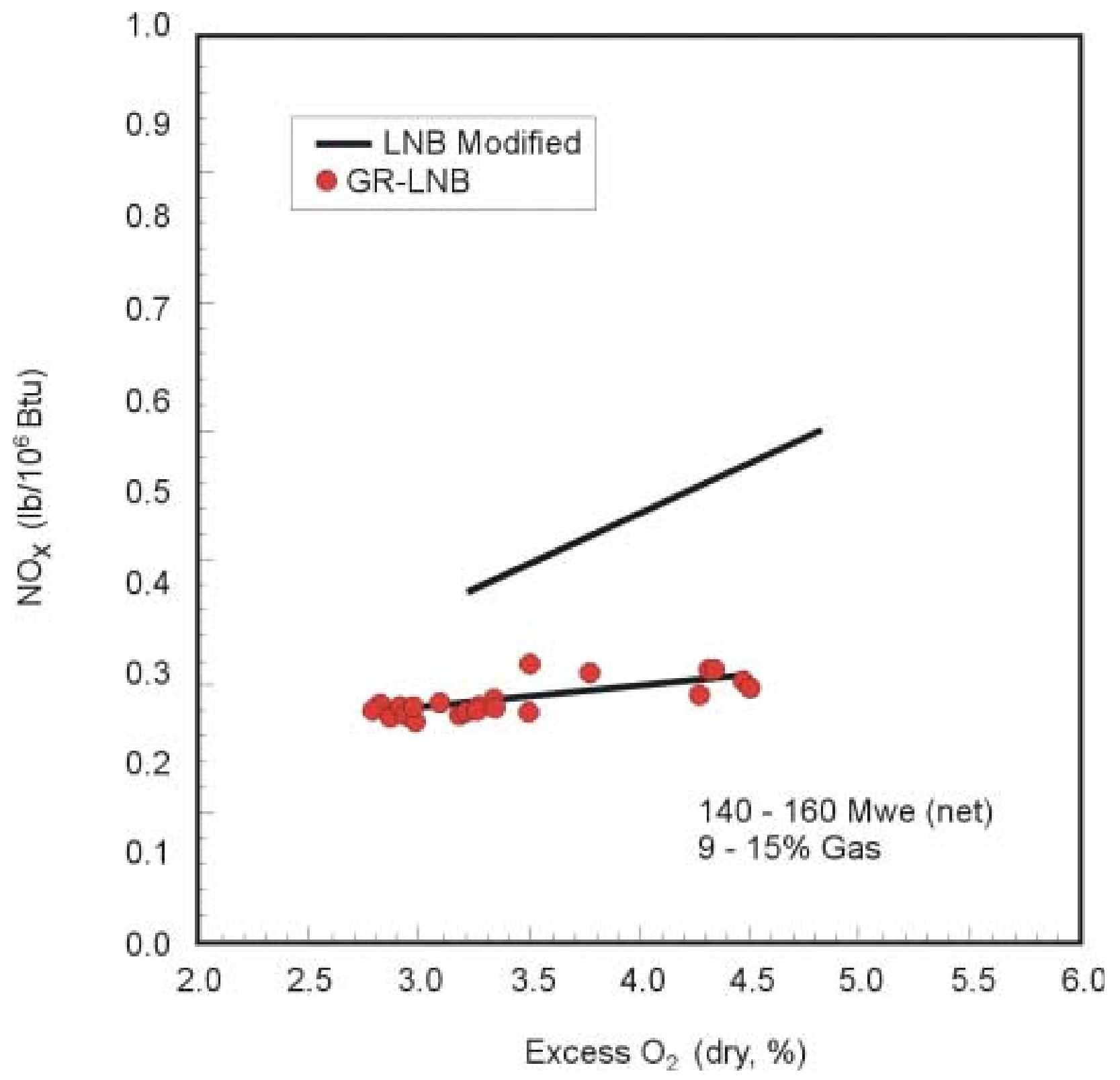

Figure 10. Effect of Exit Flue Gas $\mathrm{O}_{2}$ Concentration on $\mathrm{NO}_{\mathrm{x}}$ Emissions, Second-Generation GR 

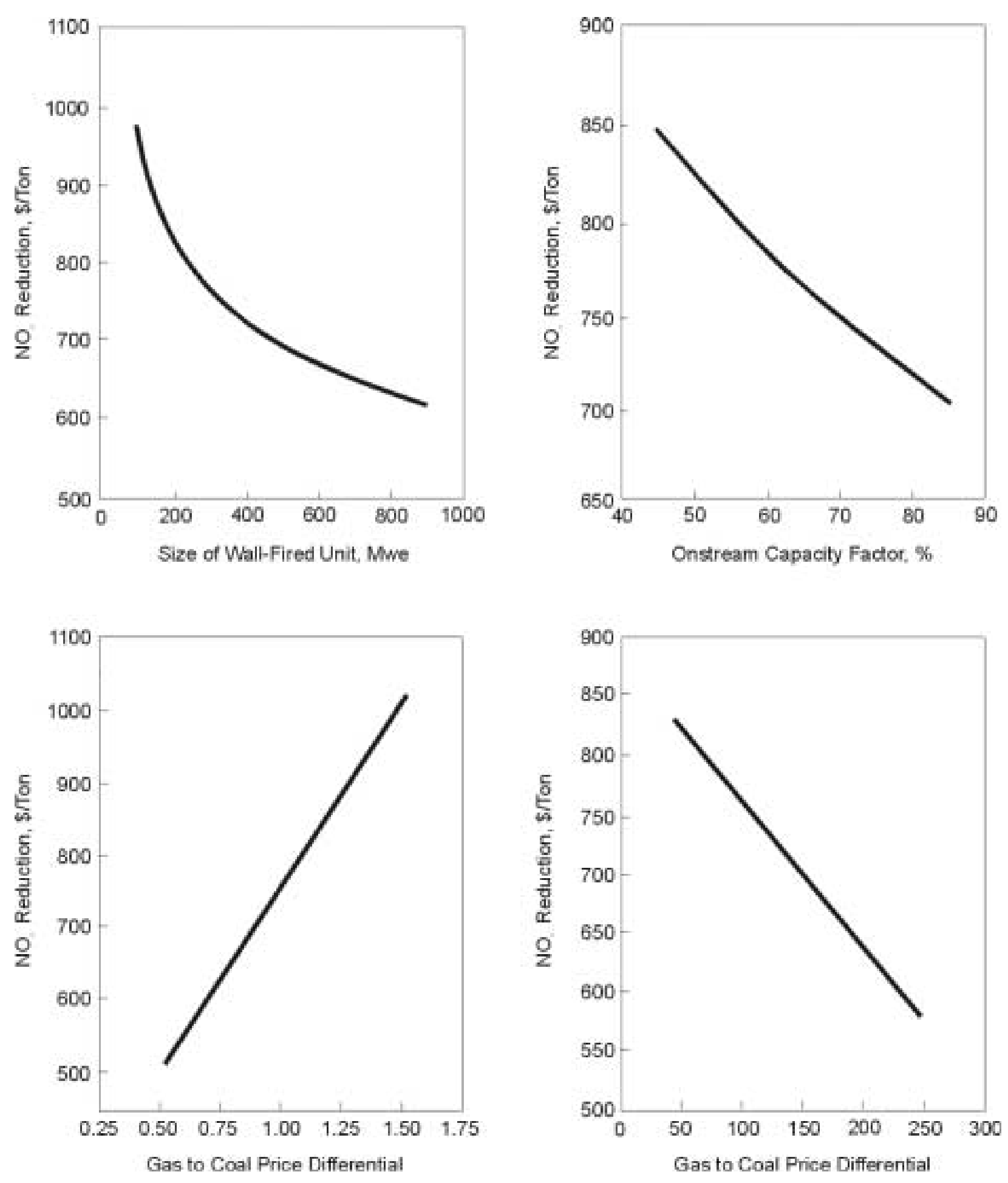

Figure 11. Effect of Operating Variables on Economics of GR-LNB Process 


\section{ABBREVIATIONS}

$\begin{array}{ll}\text { CCT } & \text { Clean Coal Technology } \\ \text { EER } & \text { Energy and Environmental Research Corporation } \\ \text { PSCo } & \text { Public Service Company (of Colorado) } \\ \mathrm{NO}_{\mathrm{x}} & \text { Nitrogen oxides } \\ \text { GR } & \text { Gas Reburning } \\ \text { LNB } & \text { Low-NO } \text { Nurners }_{\text {B }} \text { Burn } \\ \text { GR-LNB } & \text { Gas Reburning used in conjunction with Low-NO } \text { Burners } \\ \text { OFA } & \text { Overfire Air } \\ \text { NSPS } & \text { New Source Performance Standards } \\ \text { CAAA } & \text { Clean Air Act Amendments } \\ \text { CH } & \text { Methane } \\ \text { FGR } & \text { Flue Gas Recirculation }\end{array}$

